\title{
日本人の成人血清総コレステロール值
}

総合健診受診者における全国実態調査

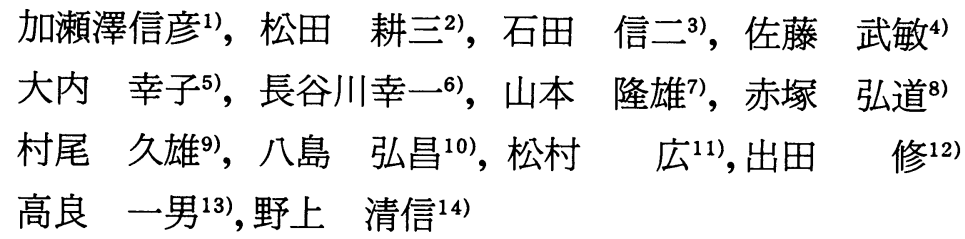

目的

近年, 日本医師会の全国臨床検査精度管理調查 で，血清総コレステロール測定值の施設間誤差と して変動係数が $3 \%$ に近づくなど, 本項目の検査 精度がきわめて向上し, かつ安定してきている事 実が報告1さされている。また測定法について見る と，最近ではわが国のほぼ $100 \%$ 近くが酵素的測 定法に統一されている。さらに自動分析機器の進 歩・普及により，その誤差内容が偶発的誤差によ るものよりも大部分が系統的誤差で占められるに 至っている2。。こような現状は, 日本総合健診医 学会の長年にわたるコントロール・サーベイの成 績においても確認されている3)。このことは健診 施設間に存在する測定値の差異を適切なデー夕補 正を行うことによって実用上解消し，データの相 互利用の可能性を示唆するものであると考えられ る。

\section{The Actual Conditions of the Serum Total Cholesterol Levels of Japanese Adult Subjects in Multiphasic} Health Testing and Services (MHTS).

1) 静岡健康管理センター ${ }^{2)}$ 札幌健診センター

3) 仙台市立病院 4) 三愛会群馬診療所

5) 聖路加国際病院 $\quad$ 6) 新潟県健康管理協会

7) 岐阜県立健康管理院 8) 愛知県総合保健センター

9) PL 大阪健康管理センター ${ }^{10)}$ 広島中央健診所

11) 高知検診クリニック 12 福岡健康管理センター

13) 琉生病院

(1990 年 3 月 30 日受稿)
他方, 血清総コレステロール值が近年增加しつ つある動脈硬化性疾患のリスクを考える際によい 指標の一つであることは, 既に周知の事実として 広く実地の健康管理に利用されており，いわゆる 成人病予防の見地からこの血清総コレステロール 值の全国実態を把握することの意義が見い出され る。

本試みは，安定した検査精度を有する健診施設 の当該地域における受診者のデー夕を全国的規模 で集積し，施設系統誤差を是正した上で，日本人 の正常值について考察し,さらにその疫学的応用 に資することの可能性について検討を行おうとす るものである。

\section{対象と方法}

\section{1. 調查対象施設の選定}

日本総合健診医学会（以下，日健診と略す）所 属の施設会員 140 施設の内から, 同会精度管理委 員会による長期検查精度良好なる推薦があり，か つ地域分布を考慮して抽出された北海道から沖縄 に至る 13 施設を本調査における共同研究施設と した (表 1 )。

\section{2. 予備調查}

日健診主催の 1989 年第 2 回コントロール・サー ベイ（ 6 月実施）を利用して, 血清 5 試料につき 測定時の “生データ” の提出を上記 13 施設に依頼 した。これを集計・解析して，抽出施設の測定値 の分布状況と誤差の大きさを予めチェックした。

3. リファレンス・ラボラトリーの設定 
表 1 調查対象・共同研究施設

\section{共同研究施設}

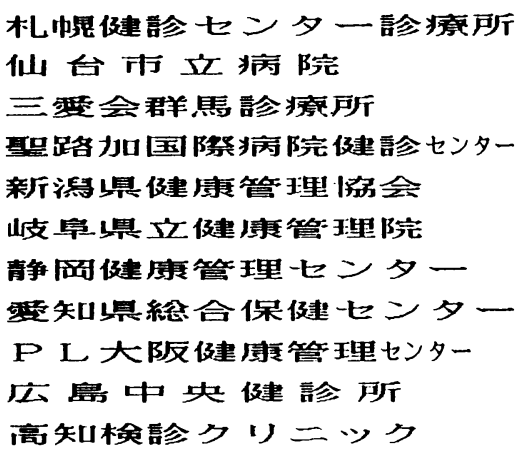

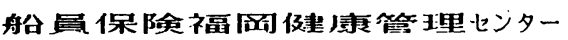

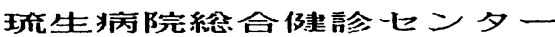

$$
\text { リファレンス・ラボ }
$$

\section{三井記念病院吅央娭查部}

精度管理に関する研究でわが国の指導的な立場 にあり，かつ実務面においてもその検查室の精度 が当該年度における国内（日本医師会サーベイ） および国外（アメリカ臨床病理医協会サーベイ： CAP）の成績によって保証されていることという 条件設定に基づき, 三井記念病院中央検査部（東 京都千代田区神田和泉町）を本調査におけるリフ アレンス・ラボラトリーとした。

\section{4. 施設間誤差の是正法}

静岡健康管理センターの「1日人間ドック」受 診者から採取された血清を 2 濃度（正常域下限お よび上限付近）に分けてプールしておき，これを 最終的に $3 \mathrm{ml}$ づつバイアル分注し凍結乾燥処理 を行ったものを補正用血清試料とした。この試料 を用いて総コレステロール (以下, $\mathrm{T}-\mathrm{C}$ と略す) につき，13 施設とリファレンス・ラボの双方で同 じ時期に 20 回測定した。次に両者の $\mathrm{T}-\mathrm{C}$ 測定平 均值を求め, $\mathrm{xy}$ 座標上でそれぞれ 2 点の平均值を 通る直線式 (一次関数) を施設ごとに算出した。 この式を用いて，各施設全データについて施設測 定值からリファレンス・ラボ值への変換を行った。

本法では, サーベイ試料の測定・報告過程と実 際の日常健診のそれとがデー夕処理法を含めて検 查室内で同一な手順で行われていることが前提と
される。この点に関しては, 予め本調査の目的と 意義および方法論について各施設に十分に理解を 求め賛同を得た上で，実測生デー夕の提出を徹底 するように協力を要請した。

\section{5. コントロール・サーベイの実施計画}

T-Cには季節的変動を示すという報告4)があ る。そこで，その影響を出来るだけ少なくするた めに本調查を秋（ 9 月〜10月）に実施する計画を 立てた。

\section{（a） 配布試料}

配布試料としては，前述の補正用血清試料 2 濃 度のほかに, 水溶性 T-C 標準液「アナセラム；第 一化学」および市販管理血清凍結乾燥品「リピッ ド・セーラム; 栄研化学」を加えて, 合計 4 種類 20 本とした。これらを 9 月 25 日に「クール宅急 便， $5^{\circ} \mathrm{C}$ 保冷」にて全国の施設とリファレンス・ラ ボに静岡より発送した。

（b） サーベイ試料の測定日程と健診受診者デ 一夕の収集方法

サーベイ試料の測定は 1989 年 9 月 28 日〜 10 月 14 日のうちの任意の 8 日間とし, 期間中, 試料 を 20 回測定した。また, 受診者データの収集期間 をほほ同時期にあたる 9 月 18 日〜 10月 14 日と し, その期間中に 20〜 39, 40〜 49 および 50〜69 歳 の各年齢区分別に男女各々 200 例以内の実測デー 夕を全数もしくはランダムに集積した。サンプリ ングの対象は総合健診（一日人間ドック）の全受 診者とした。報告書の回答期限を 10 月 23 日とし た。

6. 使用正常値と精度管理法のアンケート調査 各施設の使用正常值と精度管理法の実状を把握 するために, サーベイと併行してアンケート調査 を行った。

\section{7. 正常値設定の方法論}

現在, 多くの検査室でよく利用されており, か つその実用的価值が認知されている代表的な 4 種 類の臨床参考範囲（正常值）算出方法，すなわち (1)確率紙（正規確率および対数正規確率紙）を用 いて 2.5〜97.5 パーセンタイルの範囲にある TC 值を求める方法 (確率紙法と略す), (2)実際に得 られた分布型に最も近似すると考えられる分布曲 線を当てはめてデー夕を正規化処理し，その平均 
値 \pm 2 標準偏差 $(\mathrm{SD})$ 值の範囲に該当する T-C 值 を算出する方法(パラメトリック法), (3)分布型と は無関係に, データの低值側と高值側の両端から それぞれ $2.5 \%$ を除いた範囲を求める方法（ノン パラメトリック法), (4)パーソナル・コンピュータ を用いて計算する臼井らの考案による Clinical Reference Range Program（C.R.R.P 法）につい て，それぞれ検討した5)。

\section{8. 地域差についての解析方法}

本検討では地域差の要因について，コレステロ ール含有量の多い食品の摂取指標として「卵」な らびに「たらこ」の年間家計支出額, 経済活性の 総合指標として「県民所得額」, ライフ・スタイル の欧米化の指標として「特級ウィスキー」および 「肉類」の年間家計支出額, 都市型生活意識の一指 標として全国県民意識調査 ${ }^{6}$ における「新しいこ とへの積極的志向度合」, そして「循環器疾患受療 率」と「心疾患死亡率」, 本調査で得られた「男子 $\mathrm{T}-\mathrm{C}$ 年齢 3 区分別平均值」との合わせて 11 項目 をパラメーターとするクラスター分析（標準化ユ ーグリッド平方距離による群平均法）により解析 を行った。

なお, 本調査の統計処理には, MCP (Micro Computer Program：国際試薬(株)提供）および 多変量解析パッケージ（JRI）のソフトを使用し た。

\section{成 績}

\section{1. サーベイ結果}

コントロール・サーベイ成績を表 2 にまとめて 示した。

試料 $\mathrm{A}$ 及び $\mathrm{B}$, 並びに標準水溶液, コントロー ル血清のいずれにおいても, 13 施設の平均 T-C の変動係数 $(\mathrm{CV})$ は $2 \%$ \%ラインにあり, 精度が 良好にコントロールされている現状が示された。 また, 各施設内部精度についても, 多くの施設で CV $1 \%$ \%下の好成績が示された。

次に 13 施設の平均值をリファレンス・ラボのそ れと比較してみると, 試料 A, B ではそれぞれ 1.8 $\%, 2.1 \%$ 低值の傾向がみられたが, 標準水溶液お よびコントロール血清の平均值においては両者間 で一致する成績が得られた。期間中のリファレン
ス・ラボの $\mathrm{T}-\mathrm{C}$ 測定精度は, $\overline{\mathrm{X}}-\mathrm{R}$ 管理図を中心と する諸種内部精度管理状況において異常を認め ず，外部精度管理成績と共に良好な精度を保持し ていることが確認された。

使用している分析機器や試薬キット類は各施設 多様であるが, すべての施設で T-C について酵素 的測定法を採用していることが確認された。

なお，使用正常值についてのアンケート回答で は，サーベイ施設の測定値と使用正常値との間に 何らの関係も見られず，その上限值を一様に 250 $\mathrm{mg} / \mathrm{dl}$ と設定している施設が多いことが判明し た。

\section{2. 施設系統的誤差の確認とその要因}

試料 A と B につき， 13 施設 260 個の測定値の ツイン・プロットと, リファレンス・ラボ測定平 均值を図 1 に示した。13 施設の測定值において は, 相関係数 $\gamma=0.85$ と高い正の相関が示され, すべてのツイン・プロットが一直線上に並んだ図 から，系統的誤差の存在が明らかに認められた。 リファレンス・ラボの測定平均值は, これら散布 集団の中央部上方に位置した。

系統的誤差要因について，使用している較正物 質（キャリブレーター）の種類による分類法でデ 一夕の差異を比較した(図 2 )。市販凍結乾燥管理 血清を自家検定して 2 次キャリブレーターとして 用いている 5 施設と，プール血清を同様に自施設 で濃度評定して日常の検査に用いている 2 施設の $\mathrm{T}-\mathrm{C}$ デー夕間にやや乘離傾向がみられた。さら に, 液状管理血清を使用しその表示値通りに設定 している施設では，データが高值に偏る傾向が観

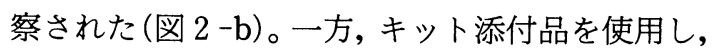
表示值通りにキャリブレーションしている 6 施設 では測定值が広範囲に分散していた（図 2-a）。

次に, 使用試薬キットのメーカー別にデータを 比較した(図 3 )。13 施設で 7 種類ものキットが使 用されており，T-Cデー夕は広範囲に散在する状 況を呈していた。これより，使用するキットによ ってデータが乘離する可能性があると考えられ た。

\section{3. 各施設補正一次式の算出}

施設系統的誤差を修正し, データの標準化を行 うために, 試料 $\mathrm{A}$ および $\mathrm{B}$ の実測平均値を用い 
表 2 コントロール・サーベイ成績表

\begin{tabular}{|c|c|c|c|c|c|c|c|c|c|c|}
\hline \multirow{2}{*}{$\begin{array}{c}\text { 施設名 } \\
\mathrm{A}\end{array}$} & \multirow{2}{*}{$\begin{array}{c}\begin{array}{l}\text { データ } \\
\text { 回収日 }\end{array} \\
10 / 31\end{array}$} & \multicolumn{2}{|c|}{ 钲 $\mathrm{A}$} & $\begin{array}{l}\text { 曾式 } \\
\text { Mean }\end{array}$ & $B$ & $\mathrm{~B} / \mathrm{A}$ & \multicolumn{2}{|c|}{$\begin{array}{l}\text { アナ七うム } \\
\text { (第一化学) }\end{array}$} & \multicolumn{2}{|c|}{ 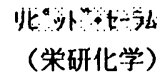 } \\
\hline & & 131.35 & 1.57 & 214.40 & 2.41 & 1.632 & 210.0 & 1.41 & 157.9 & 1.52 \\
\hline $\mathrm{B}$ & $10 / 21$ & 134.55 & 1.28 & 220.40 & 2.58 & 1.638 & 204.1 & 2.08 & 157.1 & 1.29 \\
\hline $\mathrm{C}$ & $10 / 23$ & 134.75 & 0.97 & 222.05 & 2.11 & 1.648 & 198.9 & 1.95 & 156.9 & 1.25 \\
\hline $\mathrm{D}$ & $10 / 23$ & 135.35 & 1.23 & 222.00 & 1.21 & 1.640 & 199.3 & 0.67 & 155.9 & 0.74 \\
\hline $\mathrm{E}$ & $10 / 23$ & 135.60 & 0.99 & 219.30 & 1.13 & 1.617 & 205.6 & 1.94 & 157.7 & 0.95 \\
\hline $\mathrm{F}$ & $10 / 24$ & 136.25 & 0.85 & 223.40 & 1.54 & 1.640 & 199.7 & 1.25 & 157.4 & 0.97 \\
\hline G & $10 / 23$ & 136.30 & 0.73 & 222.25 & 1.33 & 1.631 & 196.3 & 1.06 & 158.4 & 0.84 \\
\hline $\mathrm{H}$ & $10 / 23$ & 138.00 & 1.69 & 222.30 & 1.75 & 1.611 & 208.6 & 0.52 & 157.8 & 0.92 \\
\hline I & $10 / 20$ & 139.00 & 1.03 & 225.05 & 1.15 & 1.619 & 200.0 & 2.05 & 163.7 & 0.95 \\
\hline $\mathrm{J}$ & $10 / 20$ & 139.10 & 1.41 & 226.20 & 1.64 & 1.626 & 204.4 & 2.70 & 162.6 & 1.35 \\
\hline $\mathrm{K}$ & $10 / 18$ & 140.15 & 1.79 & 230.80 & 1.74 & 1.617 & 206.1 & 1.10 & 160.3 & 0.67 \\
\hline $\mathrm{L}$ & $10 / 24$ & 141.15 & 1.79 & 230.25 & 3.26 & 1.631 & 206.5 & 1.96 & 163.1 & 1.97 \\
\hline $\mathrm{M}$ & $10 / 21$ & 143.50 & 0.95 & 233.80 & 1.28 & 1.629 & 211.1 & 1.45 & 164.8 & 1.03 \\
\hline \multicolumn{2}{|c|}{ MEAN } & \multicolumn{2}{|c|}{137.32} & \multicolumn{2}{|l|}{224.02} & \multirow[t]{3}{*}{1.632} & \multicolumn{2}{|c|}{203.9} & \multicolumn{2}{|c|}{159.5} \\
\hline \multicolumn{2}{|c|}{ S. D. } & \multicolumn{2}{|c|}{3.25} & \multicolumn{2}{|l|}{5.23} & & \multicolumn{2}{|r|}{4.7} & & 3.0 \\
\hline \multicolumn{2}{|c|}{$\mathrm{C} \mathrm{V}(\%)$} & \multicolumn{2}{|l|}{2.37} & \multicolumn{2}{|l|}{2.33} & & \multicolumn{2}{|r|}{2.3} & & 1.9 \\
\hline \multicolumn{2}{|c|}{ リファレリス・ラボ } & \multicolumn{2}{|c|}{139.90} & \multicolumn{2}{|l|}{228.80} & 1.636 & \multicolumn{2}{|c|}{204.1} & \multicolumn{2}{|c|}{160.8} \\
\hline
\end{tabular}

\begin{tabular}{|c|c|c|c|c|c|c|c|}
\hline \multirow{2}{*}{$\frac{\text { 施設名 }}{\mathrm{A}}$} & \multirow{2}{*}{$\begin{array}{l}\begin{array}{l}\text { 㝬料 } \\
\text { Mean }\end{array} \\
131.35\end{array}$} & \multirow{2}{*}{$\begin{array}{l}\begin{array}{l}\text { sey } \\
\text { Mean }\end{array} \\
214.40\end{array}$} & \multirow{2}{*}{$\frac{\begin{array}{c}\text { 使用证常值 } \\
(\mathrm{mg} / \mathrm{dl})\end{array}}{130 \sim 250}$} & \multirow{2}{*}{ 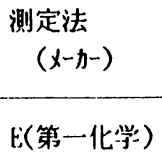 } & \multirow{2}{*}{$\frac{\text { 分析機器 }}{\text { H亡y736 }}$} & \multirow{2}{*}{ 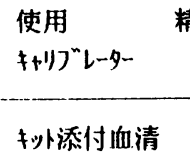 } & 情度管理法 \\
\hline & & & & & & & $\bar{x}-\mathrm{R}$ 他 \\
\hline B & 134.55 & 220.40 & $140 \sim 250$ & $E(t 0 ; ッ ク)$ & 利パス & 细清を2次Cal & $\bar{x}-R$ \\
\hline $\mathrm{C}$ & 134.75 & 222.05 & $130 \sim 250$ & $E($ 協私メデッ & 日立726 & †ット添付水溶液 & $\bar{x}-R$ 他 \\
\hline $\mathrm{D}$ & 135.35 & 222.00 & $135 \sim 260$ & $\mathrm{E}$ (片山化学) & グンイナーG & 管南を2次Cal & $\bar{x}-R$ \\
\hline $\mathrm{E}$ & 135.60 & 219.30 & $130 \sim 260$ & 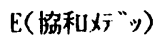 & 日立736 & キッ添付水溶液 & $\bar{x}-R$ 他 \\
\hline $\mathrm{F}$ & 136.25 & 223.40 & $122 \sim 255$ & E(日本游事) & H立736 & キッ卜添付水溶液 & $\bar{x}-R$ 他 \\
\hline $\mathrm{G}$ & 136.30 & 222.25 & $120 \sim 250$ & $\mathrm{E}$ (片山化学) & 将パス & 佔清を2次Cal & $\bar{x}-\mathrm{R}$ 他 \\
\hline $\mathrm{H}$ & 138.00 & 222.30 & $130 \sim 250$ & $\mathrm{E}$ (栄研化学) & 日标電子 & 管㞦を2次Cal & $\bar{x}-R$ \\
\hline I & 139.00 & 225.05 & $130 \sim 250$ & $E$ (第一化学) & 日立726 & キッ添付水溶液 & $\bar{x}-R$ \\
\hline $\mathrm{J}$ & 139.10 & 226.20 & $145 \sim 250$ & $E($ 和光純薬) & 東芝 $60 \mathrm{~S}$ & 管血を2次Cal & $\vec{x}-\mathrm{R}$ 他 \\
\hline $\mathrm{K}$ & 140.15 & 230.80 & $130 \sim 250$ & $E($ 協和X广 & 日立736 & 管lín.を2次Cal & $\bar{x}-R$ \\
\hline $\mathrm{L}$ & 141.15 & 230.25 & $120 \sim 230$ & $\mathrm{E}($ 協和对“”ッ) & 軎芝60R & キッ添付水溶液 & $\bar{x}-R$ \\
\hline \multirow[t]{2}{*}{$\mathrm{M}$} & 143.50 & 233.80 & $150 \sim 250$ & $E$ (栄研化学) & 東芝880 & 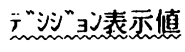 & $\bar{x}-R$ \\
\hline & & & $\begin{array}{c}\text { 最頻値 } \\
130 \sim 250\end{array}$ & $\begin{array}{l}\text { 全施設 } \\
\text { Enzymatic }\end{array}$ & $\begin{array}{l}\text { H立..6 } \\
\text { 東芒...3 }\end{array}$ & $\begin{array}{l}\text { キッ添付品. .6 } \\
\text { 管理仙清...5 }\end{array}$ & $\begin{array}{l}\text { 全施設 } \\
\bar{x}-\mathrm{R}\end{array}$ \\
\hline \multicolumn{3}{|c|}{$\begin{array}{c}\text { リファレンス・ラボ } \\
\text { (三井記念病院） }\end{array}$} & & E.(日本商事) & 東芝80S & $\begin{array}{l}\text { 管任を2次Cal } \\
\text { +方測慓淮液 }\end{array}$ & $\begin{array}{l}\bar{x}-\mathrm{R} \text { 他 } \\
\text { CAP }\end{array}$ \\
\hline
\end{tabular}




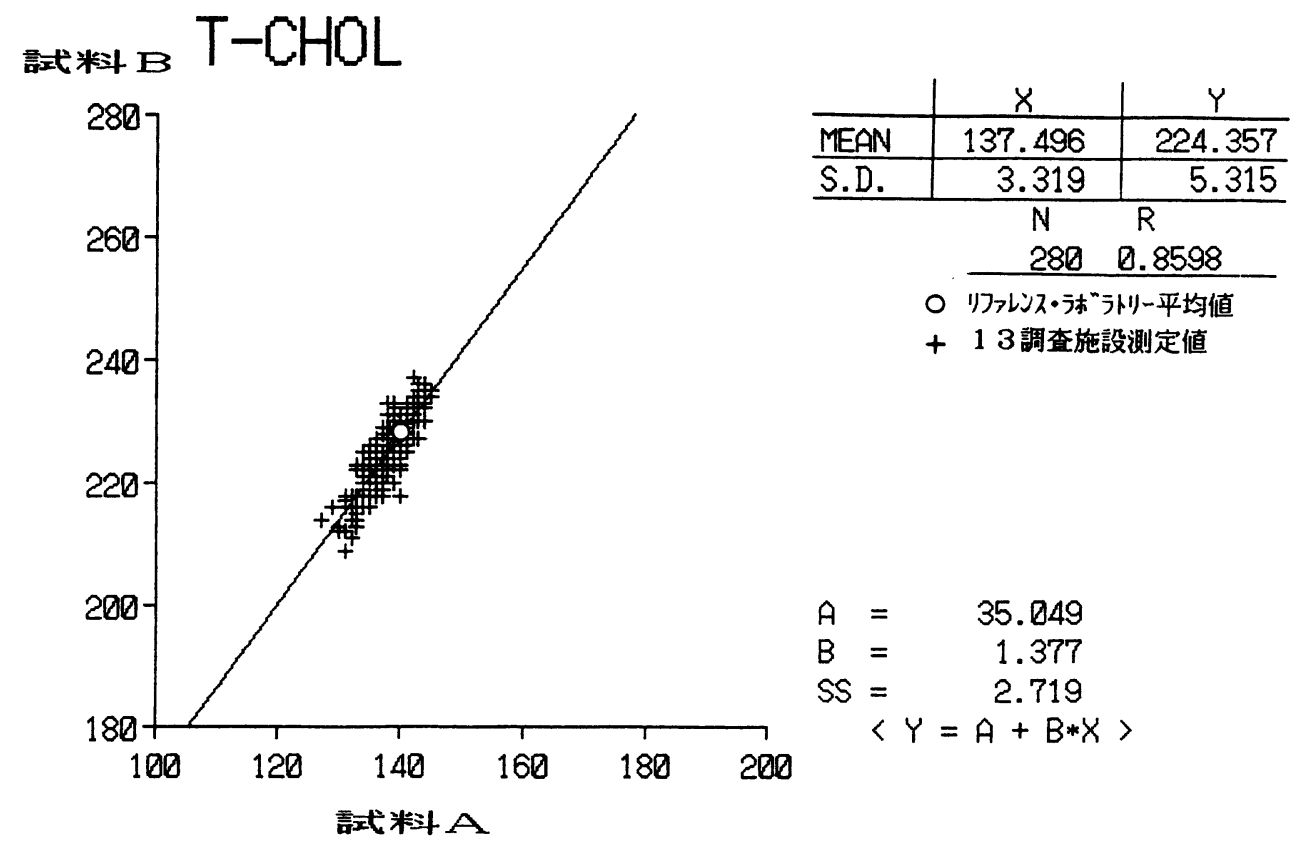

図 1 二試料測定值におけるッイン・プロット図

試米斗 B

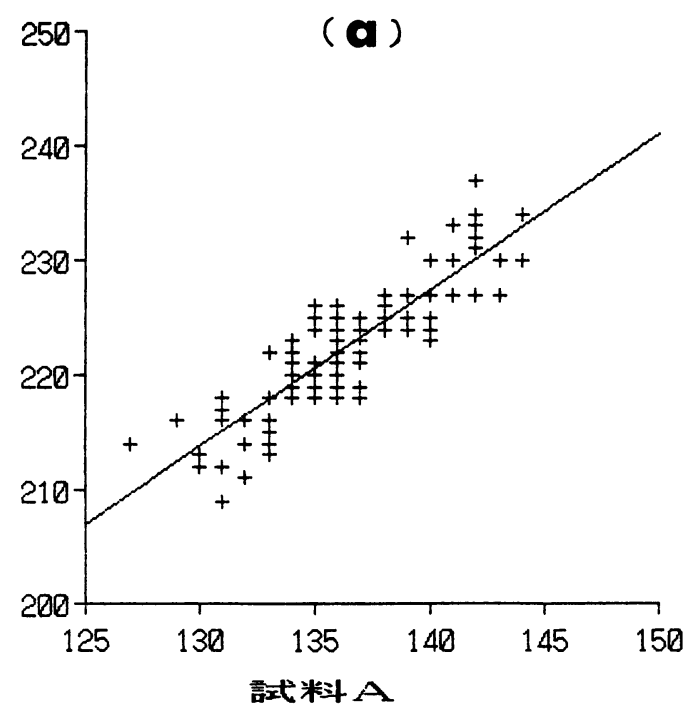

使用キャリブレーター

+ キット添付品：表示值通りにキャリブレーショコ

\section{言式米斗 B}

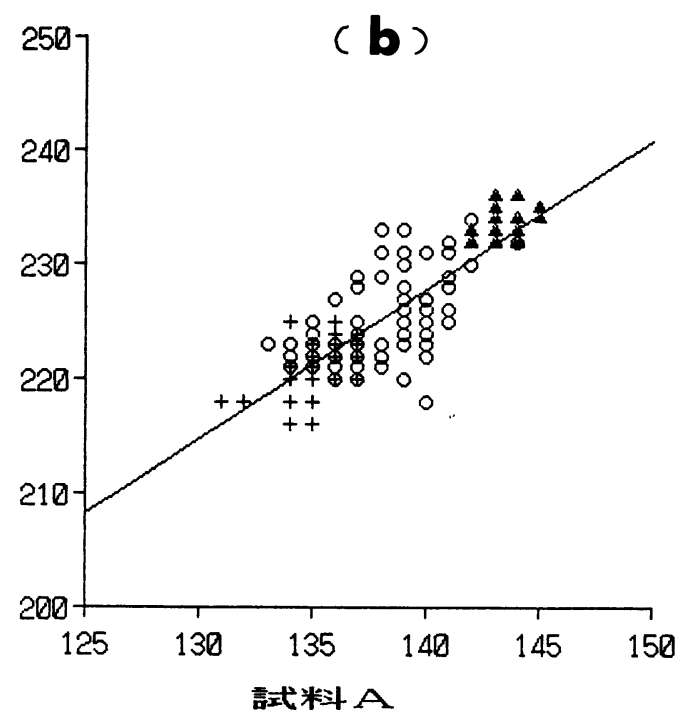

使用キャリブレーター

+ プール 血清: 自家検定による2次キ+リブレータ-

○凍乾管理血清：自家模定による2次キャリブレーター

A 液状管理血清「デシジョシ」：表示値通りに設定

図 2 使用キャリブレーターの種別測定値の分布 
日本総合健診医学会誌

表 3 リファレンス・ラボ測定值と各施設データとの関係

\begin{tabular}{|c|c|c|c|c|c|}
\hline \multirow[t]{2}{*}{ 施設No. } & \multicolumn{2}{|c|}{ サンフル実測平均値 } & \multicolumn{2}{|c|}{$y=a x+b$} & \multirow{2}{*}{$\begin{array}{c}\text { 標 準 化 } \\
\text { テータの補正式 } x=(y-b) / a\end{array}$} \\
\hline & A & B & 傾き(a) & y切片 (b) & \\
\hline 1 & 134.55 & 220.40 & 0.9657 & -0.5521 & (実測値 $+0.5521 ） / 0.9657$ \\
\hline 2 & 136.25 & 223.40 & 0.9803 & -0.8980 & （実測値 $+0.8980 ） / 0.9803$ \\
\hline 3 & 141.15 & 230.25 & 1.0022 & 0.9333 & （実測值 $-0.9333 ） / 1.0022$ \\
\hline 4 & 140.15 & 230.80 & 1.0197 & -2.5059 & （実測値 $+2.5059 ） / 1.0197$ \\
\hline 5 & 136.30 & 222.25 & 0.9668 & 1.0405 & （実測値 $-1.0405 ） / 0.9668$ \\
\hline 6 & 135.60 & 219.30 & 0.9415 & 3.8813 & (実測値 -3.8813$) / 0.9415$ \\
\hline 7 & 134.75 & 222.05 & 0.9820 & -2.6340 & （実測値 $+2.6340 ） / 0.9820$ \\
\hline 8 & 139.10 & 226.20 & & 2.0 & （実測値 $-2.0307 ） / 0.9798$ \\
\hline 9 & 135.35 & 222.00 & 0.9747 & -1.0111 & （実測値 $+1.0111 ） / 0.9747$ \\
\hline 10 & 143.50 & 233.80 & 1.0157 & 1.3949 & （実測值 $-1.3949 ） ／ 1.0157$ \\
\hline 11 & 139.00 & 225.05 & 0.9679 & 3.5831 & （実測值 $-3.5831 ） / 0.9679$ \\
\hline 12 & 138.00 & 222.30 & 0.9483 & 5.3371 & （実測値 $-5.3371 ） / 0.9483$ \\
\hline 13 & 131.35 & 214.40 & 0.9342 & 0.6542 & (実測值 -0.6542$) / 0.9342$ \\
\hline
\end{tabular}

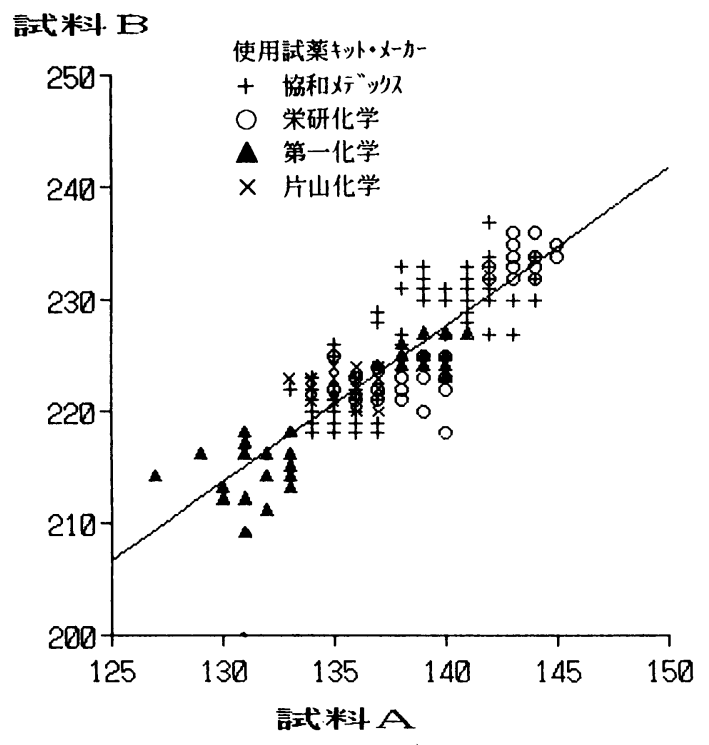

図 3 使用試薬キット別測定值の分布

てリファレンス・ラボと各施設データとの関係を 調べ，変換一次式を算出した(表 3 )。各施設ごと に算出された直線式は全体的には良くまとまって おり，ほほ比例関係が示されたが，正確には座標 原点 $(0 ， 0)$ を通らないものも見られた（図 4$) 。$ これにより，リファレンス・ラボ值を基準とした 時の各施設デー夕補正式が呈示された。

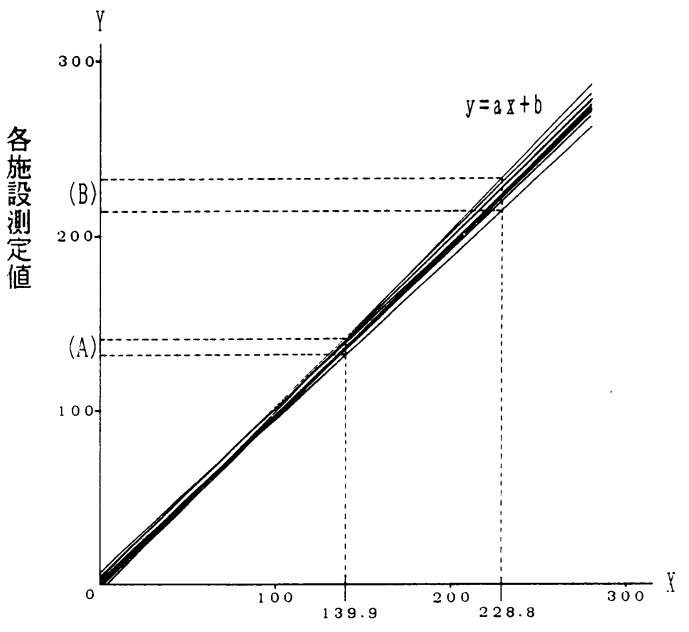

リファレンス・ラボ測定值 $(2 / d 1)$

図4 各施設データ補正直線

以後,集積された全健診デー夕 11,092 例を施設 ごとの補正式により変換した後, 各施設各年代お よび性別に平均值士 $3 \mathrm{SD}$ を超えるものを反復除 外計算を行ってそれぞれ異常デー夕を棄却した。 こうした操作により，最終的には男子 6,396 例， 女子 4,618 例の合計 11,014 例の標本が得られた ので，これらを解析に用いた。 


\section{T-C の度数分布型}

$\mathrm{T}-\mathrm{C}$ 全国集計值の性および年齢区分別度数分 布図を図 5 に示した。外観上，各ヒストグラムは いずれも正規型よりやや高值側に重心を移した分 布型であることが示されたが，対数正規分布ほど の歪みは見られなかった。

5. 各種算出法によって求められた臨床参考值 各種方法による臨床参考範囲算出の実例を, 男 子 50-69 歳群について図 6〜図 8 に示した。また, こうして得られた臨床参考範囲の成績を性・年齢 区分別にまとめて，表 4 に表した。

算出法別に得られたこれらの上限値を相互に比
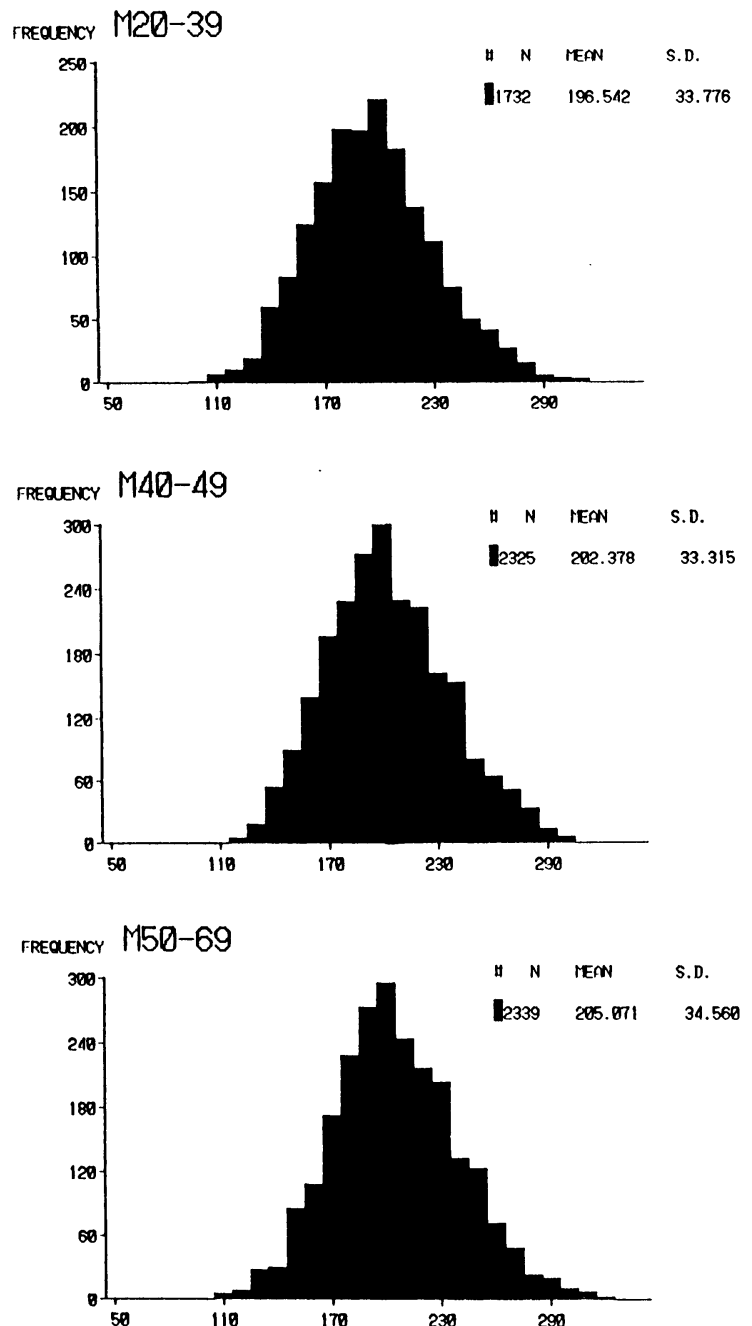

較すると，各区分に共通して，正規確率紙法と C. R.R.P 法との值が近似しており,一方, 対数正規確 率紙法とパラメトリック法およびノンパラメトリ ック法の三種類が類似した傾向の値を呈した。し かし，いずれの算出法を用いても，男子では臨床 参考範囲上限值が $270 \mathrm{mg} / \mathrm{dl}$ 前後と示され, 大差 を認めなかった。また下限值についても，男子で は $140 \mathrm{mg} / \mathrm{dl}$ 前後の值に収束しており, 各種算出 法による差異は認められなかった。女子において は，算出法別傾向は男子と同様であったが，特に 男子と比べて算出される臨床参考值が年齢区分ご とに大きく変化している成績が示された（図 9 )。
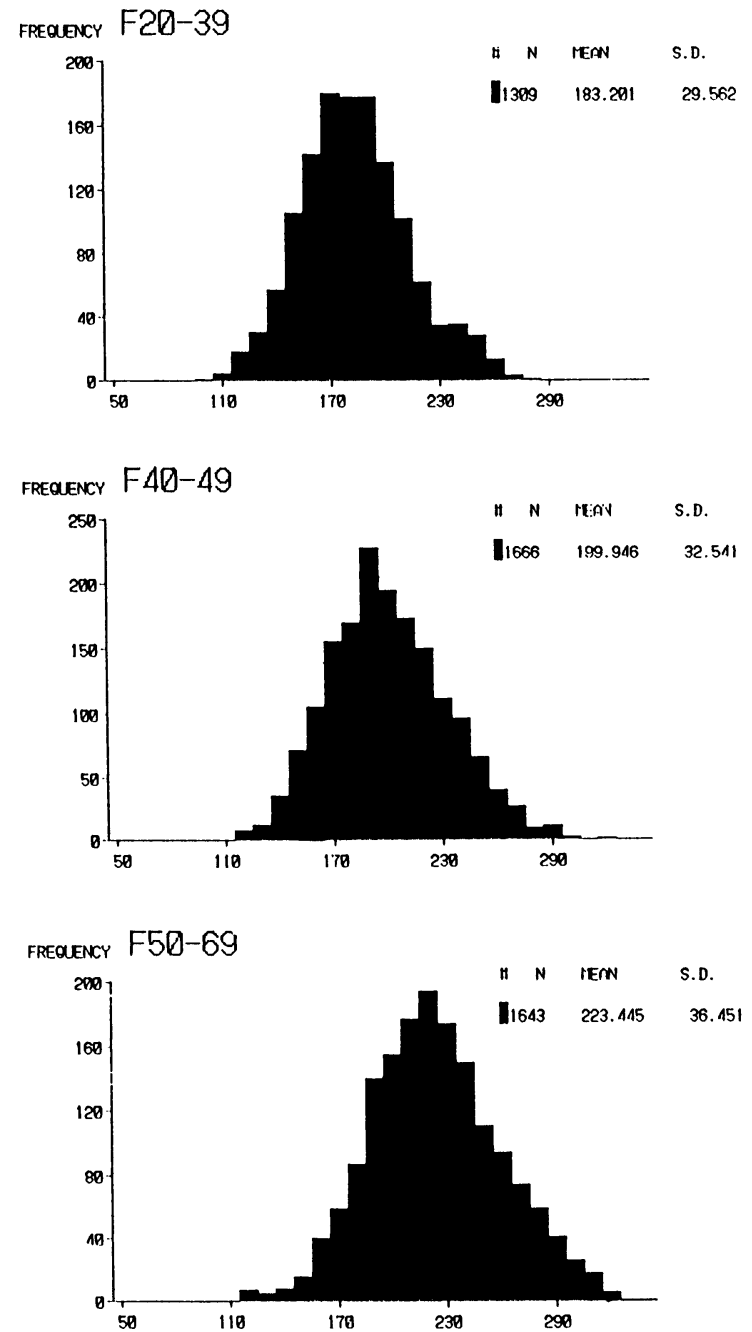

図 5 血清総コレステロール全国集計値の性・年齢区分別度数分布図 
6. 日本人の $\mathrm{T}-\mathrm{C}$ 值および性・年齢区分別平均 值

全国 13 施設の総合健診受診者 11,014 例におけ る T-C の性・年齢区分別統計值を表 5 に示した。 男子の平均值は, 20 ３9 歳が 196, 40〜 49 歳で 202, $50 \sim 69$ 歳では $205 \mathrm{mg} / \mathrm{dl}$ と加齢により漸次 増加する傾向が見られた。一方, 女子の平均值で は 20〜39 歳が183，40～49 歳で 199 と男子の同年
代よりも低值であったが, 50 ～69 歳の平均值は $223 \mathrm{mg} / \mathrm{dl}$ と著しく増加するため, 男子の值を遥 かに凌駕した成績を示した。これら本調査で示さ れた T-C 平均值の成績は, 1980 年に厚生省が調 查した「循環器疾患基礎調査 ${ }^{7} 」$ で総数 10,663 例 の日本人の平均值が男子 30 39 歳 $187,40 \sim 49$ 歳 188, 50 69 歳 $187 \mathrm{mg} / \mathrm{dl}$, 女子 30 39 歳 177 , 40〜 49歳 186, 50〜69 歳 $203 \mathrm{mg} / \mathrm{dl}$ であったこと
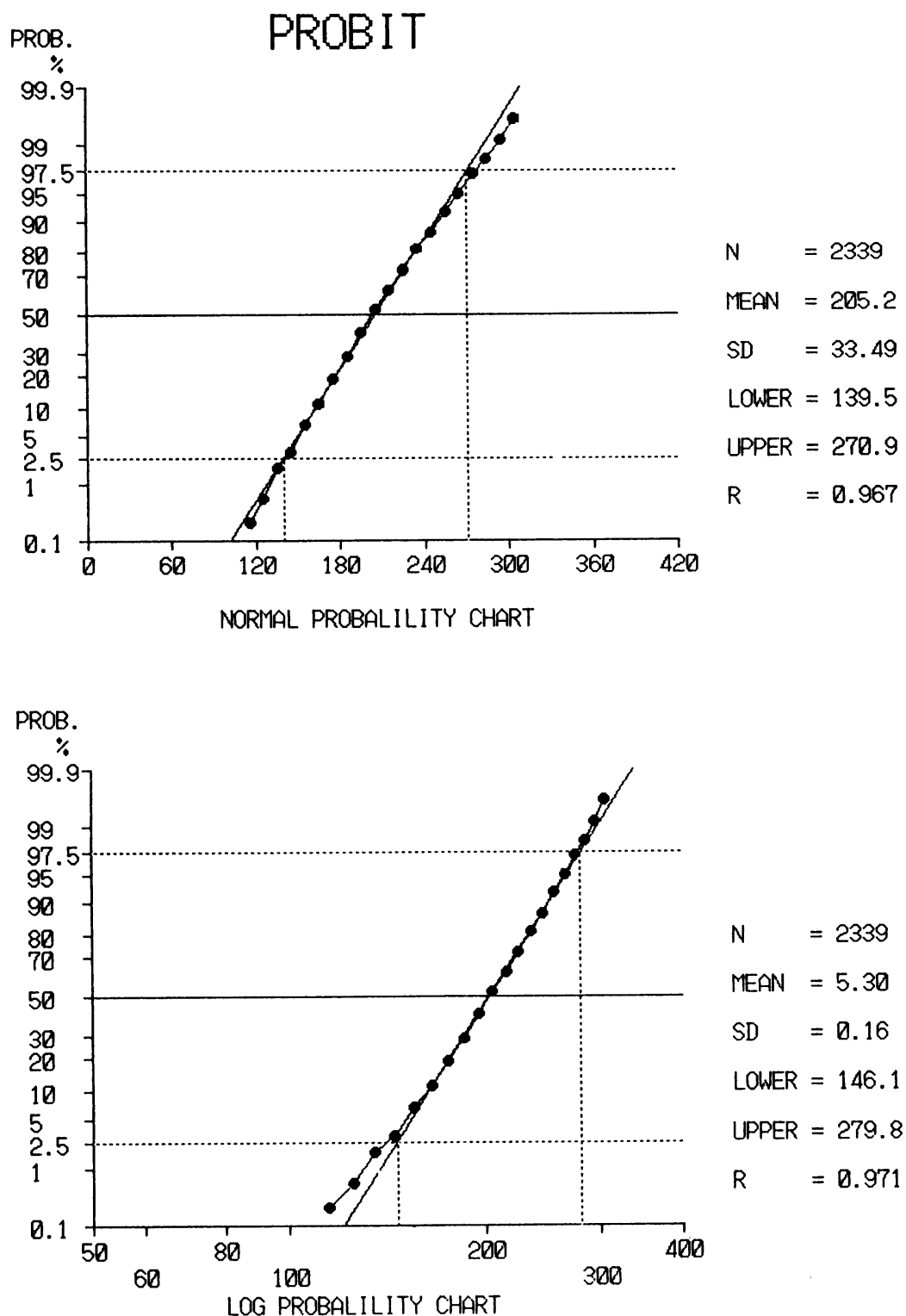

図 6 確率紙法による臨床参考範囲の算出例（男子 50-69 歳） 
と比べて, 各年代男女とも平均値として $6 \sim 20$ $\mathrm{mg} / \mathrm{dl}$ 高くなっていることが示された。なお, 全 標本平均值は本調査が $202 \mathrm{mg} / \mathrm{dl}$ であったのに 対し，1980 年の厚生省報告值では $189 \mathrm{mg} / \mathrm{dl}$, ま た同年, 五島らの行った文部省総合研究班の $\mathrm{T}-\mathrm{C}$ 調査 ${ }^{8)}$ では $191 \mathrm{mg} / \mathrm{dl}$ と報告されており，単純に これらを比較すれば， 9 年間に $12 \mathrm{mg} / \mathrm{dl}$ 高值に 推移した可能性が示された。

\section{7. 地域差とクラスター分析による要因分析}

13 施設の所在地 (都市) 別に T-C の平均值を算 出し，性および年齢区分によって比較した（図 10)。この図加ら, 全体的に東京, 名古屋, 広島, 那霸などの都市で $\mathrm{T}-\mathrm{C}$ 值が高く, 仙台, 群馬, 高
知などでは相対的に低值であることが示された。 一方, 男子平均 $\mathrm{T}-\mathrm{C}$ 值, 県民所得額, 年間家計支 出額の「ウイスキー」「肉類」「たらこ」「卵」，心 疾患死亡率, 循環器疾患受療率扔よび「新しいこ とへの積極的志向」をパラメーターとするクラス ター分析によって地域間の類似性を解析した結 果, 図 11 の日本地図分布特性から, 図 12 のごと くグループ結合が得られた。

その要因間の結び付きは，同じくクラスター分 析のデンドログラムによると，T-C 值と県民所得 が近い関係にあり，これがウイスキー消費額とひ とつのグループを形成している。一方, 肉類の消 費量と新しいことへの積極意識とが強く関連し,

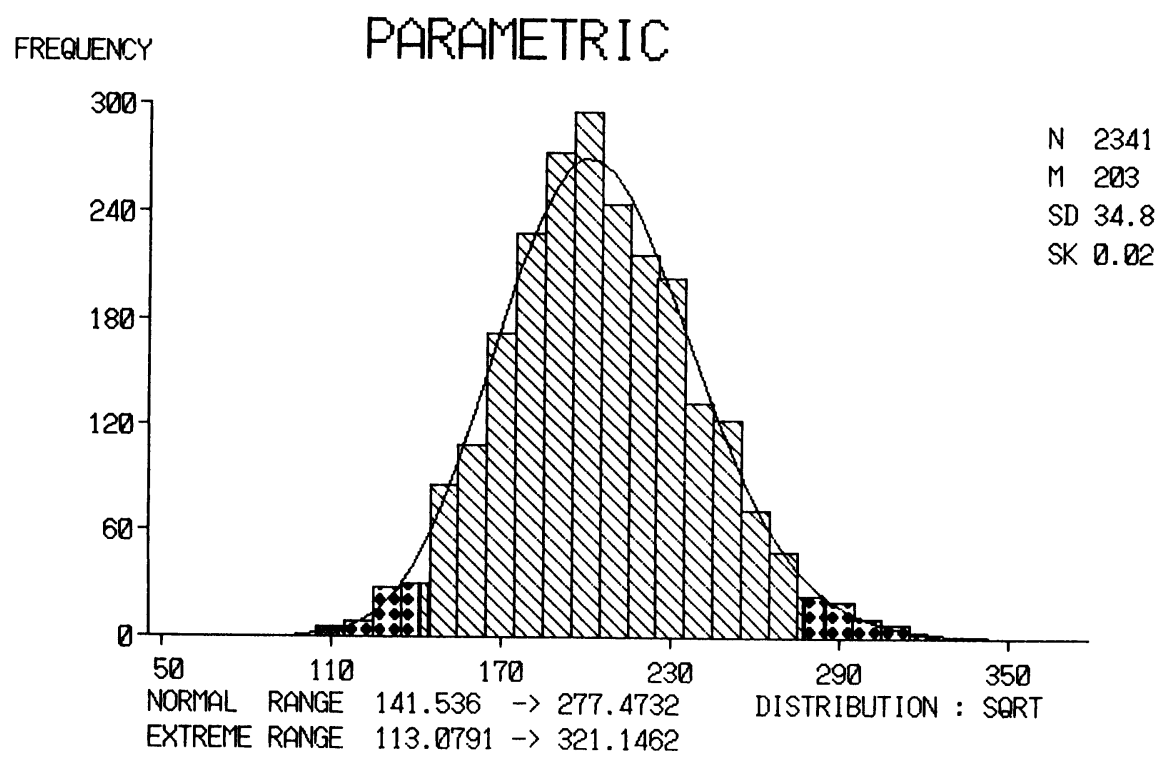

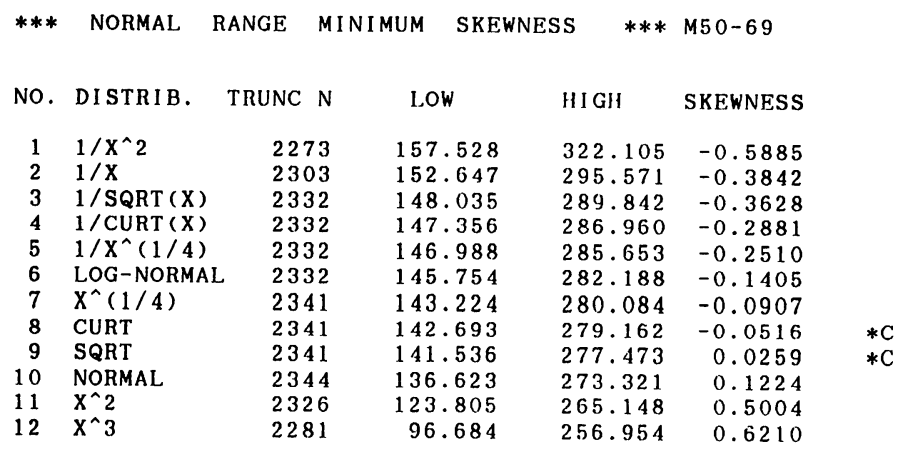

図 7 パラメトリック法による臨床参考範囲の算出例（男子 50-69 歳） 
これが心疾患死亡率ともう一つの近親グループを 成している。さらに，これら二つの要素が互いに 結合し大きなグループとなって存在している様子 が示された（図 13）。

\section{考 察}

自動分析機器の目覚ましい進歩とその普及にあ
いまって,わが国で T-C が従来の化学的測定法か ら酵素的測定法へと変遷を遂げ, 検査室に採用さ れ始めてから十数年が経過した。今日ようやく酵 素的測定法がほぼ完全に検査室に定着したと考え られる。測定精度についても年々向上する検査項 目の中にあって, 特に $\mathrm{T}-\mathrm{C}$ は安定な項目の一つと 位置づけることができる。
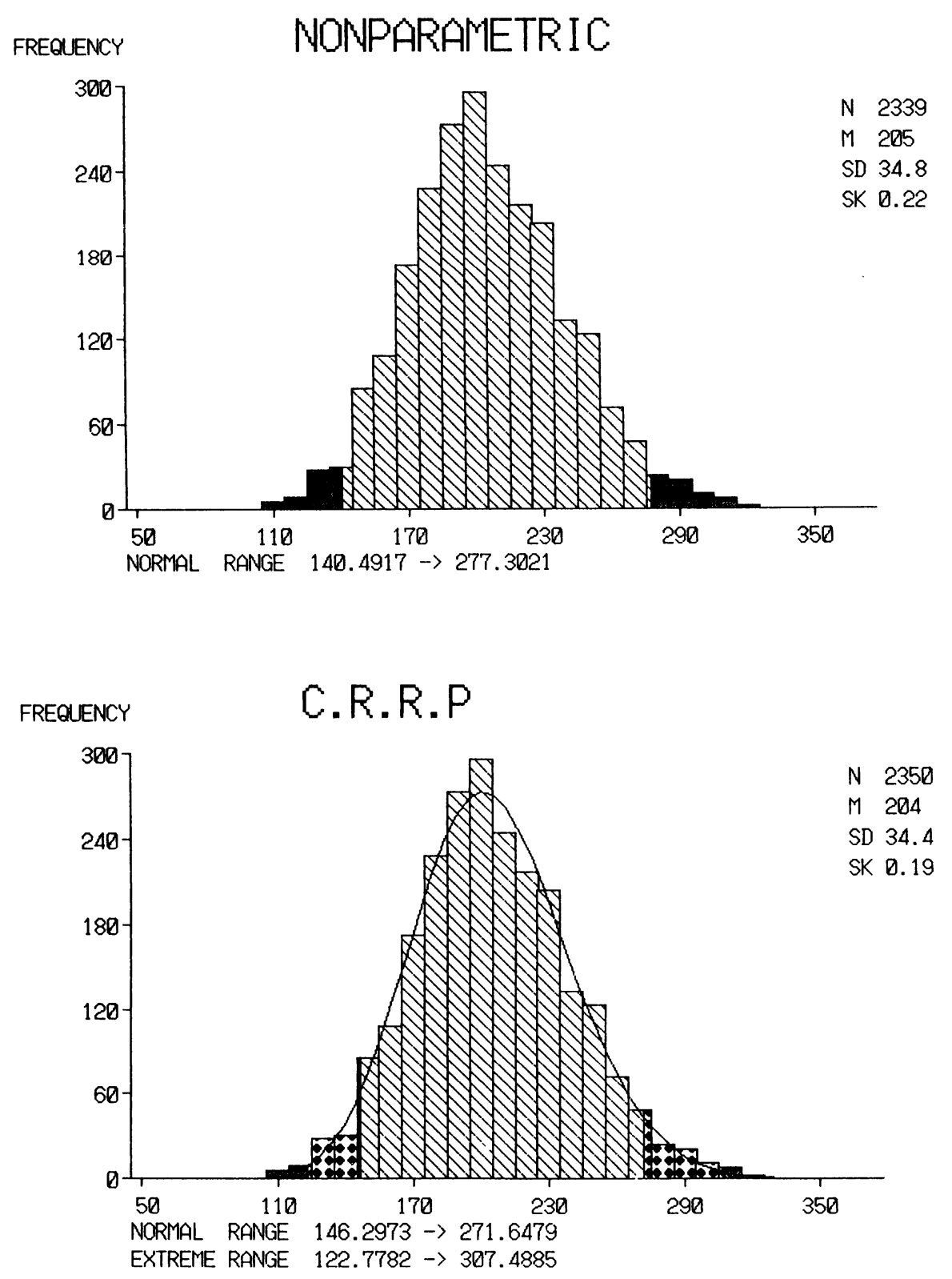

図 8 ノンパラメトリック法およびC.R.R.P 法による臨床参考範囲の算出例（男子 50-69 歳） 
このような経緯のなかで, 現在, T-C の誤差内 容の大部分が系統的誤差で占められている事実が 本サーベイ調査によっても明確に示されたため, 施設間データのバイアスを比例係数などの適切な 方法で補正することにより，データの互換利用を 可能にする方法論が考察された。

本調査では，わが国で当該検査の精度管理につ いて指導的かつ信頼度の高い一施設をリファレン ス・ラボラトリーとして位置づけ，そのデータと 各検査室測定データとの間に，正常值下限および 上限值付近濃度の受診者血清試料を介してそれぞ れその二点を通る一次直線式を設定し，デー夕補
正による基準化を行う方式を採用した。本サーベ イの成績からも示されたが，比例補正では単純に 係数（ファクター）をかけることにより行われる が，現状の両者の関係式は厳密な意味では $\mathrm{y}=\mathrm{ax}$ よりも，本法のように $\mathrm{y}=\mathrm{ax}+\mathrm{b}$ の一次式から算 出した方がより正確なデー夕補正を行うことがで きると判断されたためである。

この系統的誤差の要因として, 使用キャリブレ ーター自体の表示值の正確さに関するものと, 試 料の粘性と分析機器のサンプリング誤差に関する もの，および添加剤等による䣲素反応への干涉な どを考えることができる。市販管理血清の中には

表 4 各種方法により算出された臨床参考範囲

\section{《男》}

\begin{tabular}{|c|c|c|c|}
\hline $\begin{array}{c}\text { 年龄区分 } \\
\text { 算 出 法 }\end{array}$ & $\begin{array}{c}20 \sim 39 \text { 歳 } \\
(1,732 \text { 例 })\end{array}$ & $\begin{array}{c}40 \sim 49 \text { 歳 } \\
(2,325 \text { 例 })\end{array}$ & $\begin{array}{c}50 \sim 69 \text { 歳 } \\
(2,339 \text { 例 })\end{array}$ \\
\hline \multicolumn{4}{|l|}{ 確 率 紙 法 } \\
\hline 正規確率紙 & $132 \sim 261$ & $138 \sim 267$ & $140 \sim 271$ \\
\hline 対数正規確率纸 & $139 \sim 270$ & $145 \sim 275$ & $146 \sim 280$ \\
\hline バラメトリック法 & $137 \sim 269$ & $142 \sim 274$ & $142 \sim 277$ \\
\hline נ パラメトッック 法 & $136 \sim 269$ & $142 \sim 274$ & $141 \sim 277$ \\
\hline C.R.R.P 法 & $137 \sim 261$ & $144 \sim 270$ & $146 \sim 272$ \\
\hline
\end{tabular}

単位: $\mathrm{mg} / \mathrm{d} 1$

\section{《女》}

\begin{tabular}{|c|c|c|c|}
\hline $\begin{array}{l}\text { 年龄区分 } \\
\text { 算 出 法 }\end{array}$ & $\begin{array}{c}20 \sim 39 \text { 歳 } \\
(1,309 \text { 例 })\end{array}$ & $\begin{array}{c}40 \sim 49 \text { 歳 } \\
(1,666 \text { 例 })\end{array}$ & $\begin{array}{c}50 \sim 69 \text { 宬 } \\
(1,643 \text { 例 })\end{array}$ \\
\hline \multicolumn{4}{|l|}{ 確 率紙 法 } \\
\hline 正規碓率紙 & $127 \sim 239$ & $137 \sim 263$ & $156 \sim 292$ \\
\hline 対数正規確率紙 & $133 \sim 246$ & $144 \sim 270$ & $162 \sim 301$ \\
\hline パラメトリック法 & $130 \sim 247$ & $141 \sim 269$ & $157 \sim 299$ \\
\hline ア ペラメトッック 法 & $128 \sim 249$ & $142 \sim 268$ & $156 \sim 299$ \\
\hline C.R.R.P 法 & $135 \sim 233$ & $144 \sim 263$ & $159 \sim 294$ \\
\hline
\end{tabular}

単位: $\mathrm{mg} / \mathrm{d} 1$ 
「デシジョン」のごとく添加剤の性状により粘性が 著しく高いものがあり, 実際の受診者血清のそれ と大きく異なる場合には, 各自動分析機器の特性 に応じて試料のサンプリング誤差を生じる可能性 が大きいと考えられる。微量のサンプルであるほ ど誤差は拡大する。一方, 水溶性の標準品では溶

表 5 日本人の血清総コレステロール統計値

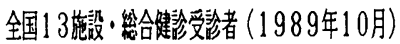

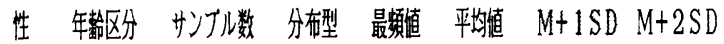

$(m g / d l) \quad(m g / d l) \quad(m g / d l) \quad(m g / d l)$

\begin{tabular}{llllllll} 
& $20 \sim 39$ & 1,732 & $X^{\wedge}(1 / 4)$ & 195 & 196 & 230 & 263 \\
男 & $40 \sim 49$ & 2,325 & $3 \sqrt{ }$ & 201 & 202 & 235 & 268 \\
& $50 \sim 69$ & 2,339 & $\sqrt{ }$ & 204 & 205 & 239 & 273 \\
\hline & & & & & & & \\
& $20 \sim 39$ & 1,309 & $X^{\wedge}(1 / 4)$ & 181 & 183 & 212 & 241 \\
女 & $40 \sim 49$ & 1,666 & $3 \sqrt{ }$ & 198 & 199 & 232 & 265 \\
& $50 \sim 69$ & 1,643 & $\sqrt{ }$ & 222 & 223 & 259 & 295 \\
\hline
\end{tabular}
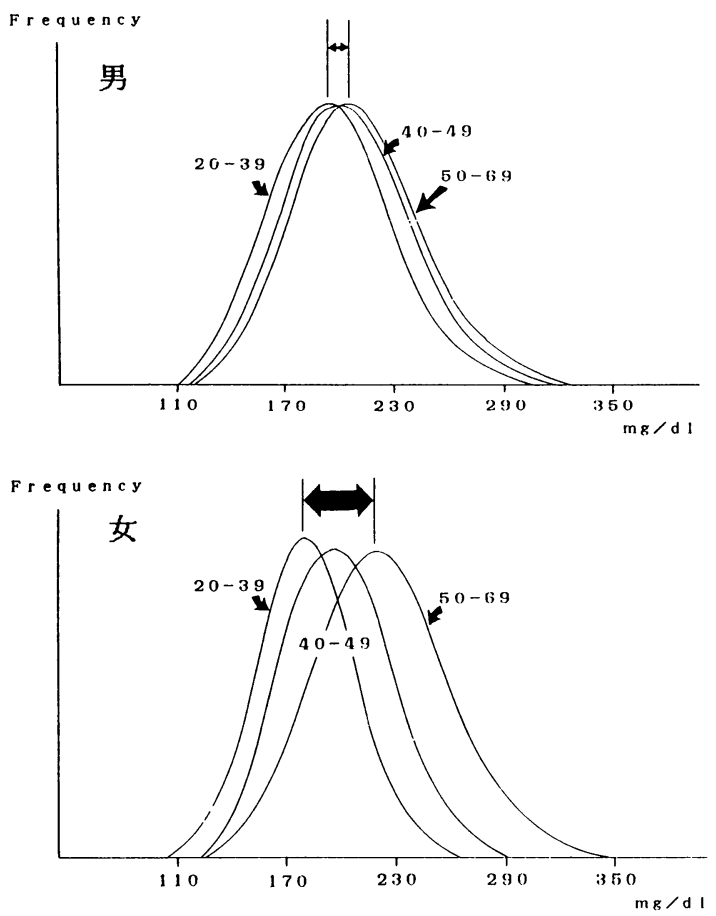

図 9 血清総コレステロールの男女別・年齢分布曲線
媒の種類や添加剂等によって酵素反応が直接ある いは間接的に影響を受ける可能性も考えられる。 また，多項目同時測定の便宜上，プール血清また は市販の管理血清の T-C 值を 2 次的に自家検定 して，これを使用している施設が多いことが判明 したが，この場合には施設検定值の正確さが問題 とされる。いずれにしても, 現状において, キャ リブレーターの種類や施設における較正方法, 並 びに分析機器のサンプリング特性等の因子が複合 的に加わって施設間に系統的差異が生じているも
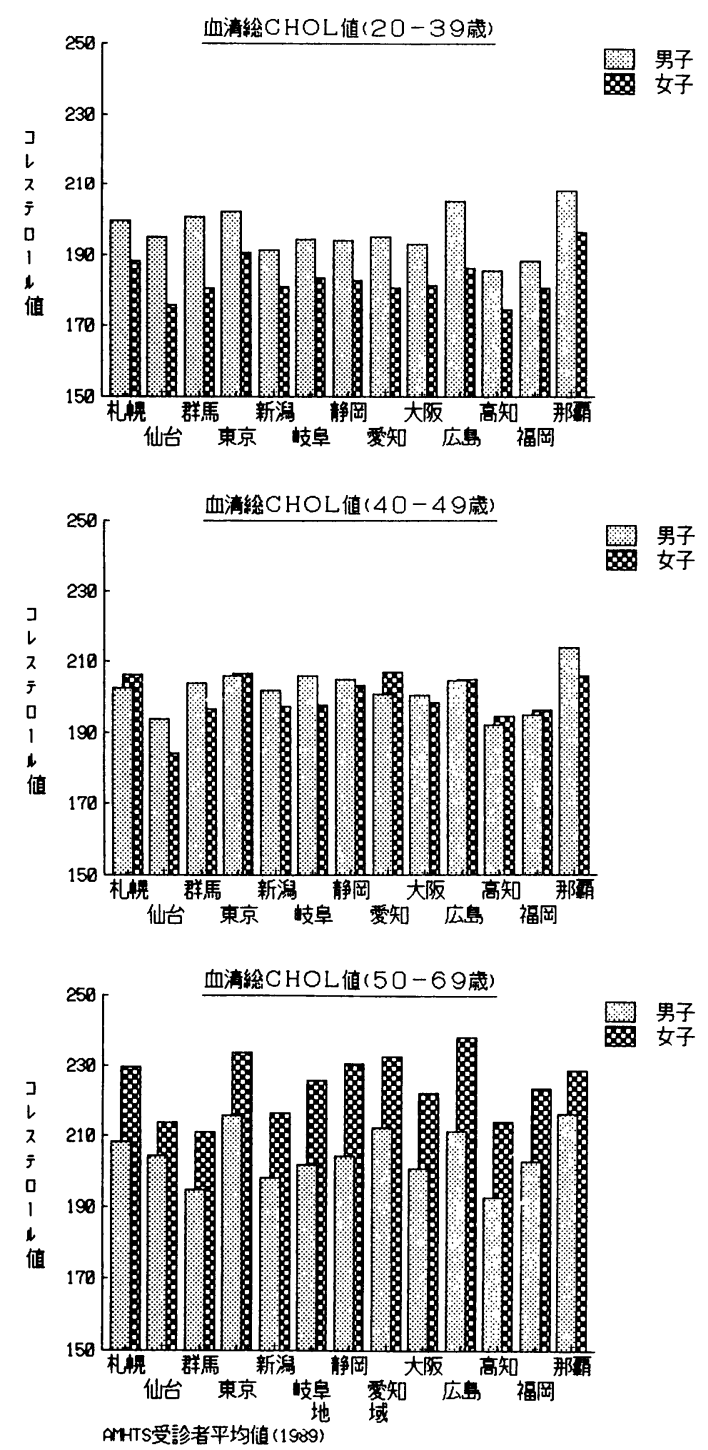

図 10 性・年齢・地域別総コレステロール平均值の動態 日健診誌 JMHTS Vol. 17 No. 31990 年 
のと推定される。したがって，この誤差を取り除 く方法としては，信頼のおけるリファレンス・ラ ボを中心として各施設のデータを修正することが 現状において最も実用的かつ有効な方法であろう

\section{総コレステロール平均値}

\section{男40-49歳}

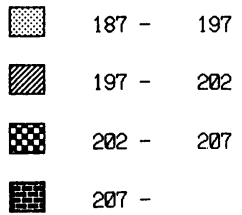

（万円）

\begin{tabular}{lll}
\hline $170-$ & 170 \\
$\mathbb{Z}$ & $170-$ & 200 \\
$200-$ & 230 \\
&
\end{tabular}

\section{人口10万対}

\begin{tabular}{|c|}
\hline 102 \\
\hline $112-$ \\
\hline $122-$ \\
\hline
\end{tabular}

図11日本地図における各パラメーターの分布特性
と考えられる。

データのサンプリングに当たって，本調査では 季節変化の影響が少ない秋の一定期間内における

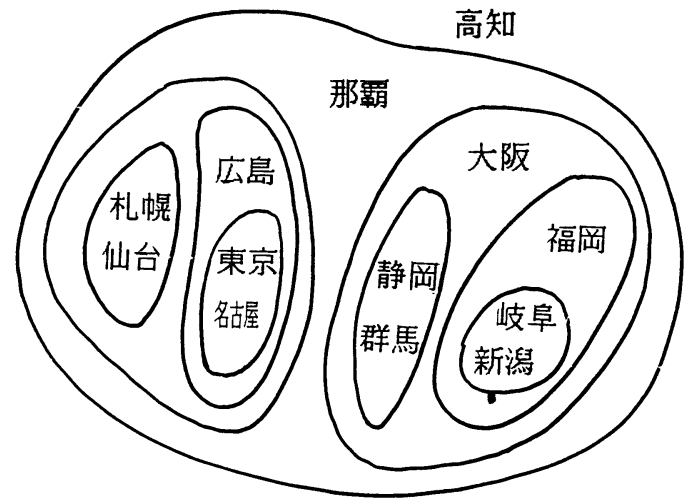

図 12 地域間の類似性（クラスター分析） パラメーター:

(1)血清総コレステロール平均值 (男 20３9 歳), (2)同 (男 $40 \sim 49$ 歳), (3)同 (男 $50 \sim 69$ 歳), (4)循環器系疾患受療 率, (5)心疾患死亡率, (6)県民所得, (7)新しいことへの積 極意識，8家計支出額「肉類」，(9)同「卵」，(10同「たら こ」, (11)同「ウイスキー」
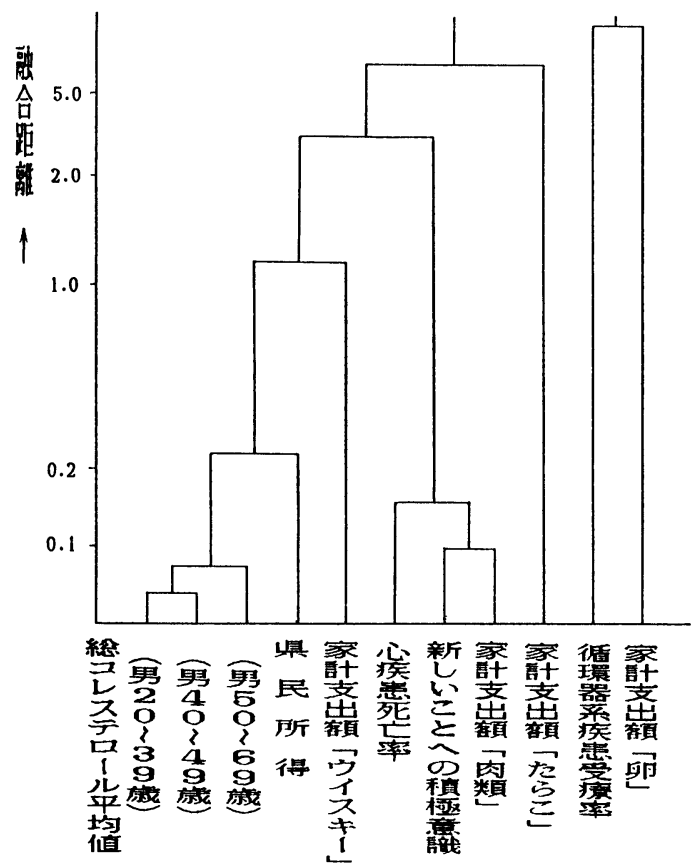

図 13 デンドログラム（クラスター分析） 
総合健診（一日人間ドック）受診者の全デー夕を 使用し, 施設データ補正後に各群の平均値 \pm 3 $\mathrm{SD}$ にて反復トランケーションを実施して異常值 を統計的に除外した。従って, 明らかな $\mathrm{T}-\mathrm{C}$ 異常 值は統計上除外されているが，臨床診断手法によ って疾病の有無をチェックされたものではなく， 用いられた標本は若干の軽度異常值を含み得るも のである。しかし，その大多数の受診者について は健康的な社会生活を行っている成人と見なすこ とができる。また，職業構成にも特記すべき偏り が見られなかったことから，サンプリングについ て妥当性があると考えられる。

このようにして本調査で示された T-C 平均値 の成績は,ほほ同じ標本数の 1980 年厚生省調査に よる「循環器疾患基礎調查」の日本人の性・年齢 区分別平均值と比べて, 各年代男女とも平均值と して $6 \sim 20 \mathrm{mg} / \mathrm{dl}$ も高くなっていることが示さ れた。また, 1989 年の本調查の全標本平均値は 202 $\mathrm{mg} / \mathrm{dl}$ であったが, 1980 年の厚生省報告值では $189 \mathrm{mg} / \mathrm{dl}$, また同年, 五島らの調査では $191 \mathrm{mg} /$ $\mathrm{dl}$ と報告されている。これらを資料として推定す るならば,ここ 10 年間に日本人の平均值が 10 $\mathrm{mg} / \mathrm{dl}$ 以上も高值に推移した可能性が指摘され る。勿論, 方法論の異なる過去の調査成績をその まま本成績值と対比すること自体, 無理があると しても，他に参照すべき資料が見あたらない現状 においては, T-Cの年次推移を大局的見地から考 察する場合に一つの寄りどころになると考えられ る。そうすると, 現在, わが国の成人 $\mathrm{T}-\mathrm{C}$ 值は漸 次増加を続けており, 将来の虚血性心疾患発症の リスクは依然として高いままに推移しているとす る疑いが濃厚である。今後, 注意深く監視する必 要があると思われる。

一方，臨床検査領域で用いられている臨床参考 値に関してこれを考察すると,参考值の上限を「平 均値十 $2 \mathrm{SD} 」$ の計算で設定されている施設が多 いことから，これを本調査成績に当てはめると， 男子 $20 \sim 39$ 歳で $263,40 \sim 49$ 歳で 268, 50〜69 歳 では $273 \mathrm{mg} / \mathrm{dl}$, 全体として $260 \sim 270 \mathrm{mg} / \mathrm{dl}$ と なり, 女子では 20〜39 歳が 241, 40〜 49 歳で 265, $50 \sim 69$ 歳では $295 \mathrm{mg} / \mathrm{dl}$, 全体として $240 \sim 295$ $\mathrm{mg} / \mathrm{dl}$ と計算された。これらの数值は, アンケー
卜調査に示された使用正常上限值の $250 \mathrm{mg} / \mathrm{dl}$ を遙かに上回るものである。さらに, 1987 年の日 本動脈硬化学会で提案された高脂血症の基準值： $220 \mathrm{mg} / \mathrm{dl}$ や, 米国 NCEP(National Cholesterol Education Program) における高コレステロール 血症の新しいガイドライン $: 240 \mathrm{mg} / \mathrm{dl}$ などと比 較すれば，これは著しく高値であることが示唆さ れる。すなわち, T-C の場合, 臨床参考範囲設定 の考え方が従来の慣例的な「平均值 $\pm 2 \mathrm{SD}$ と計 算して妥当なのかどうか, また年齢や性によって 考慮する必要はないのかどうか, 再検討すべき課 題を呈示していると考えられる。

ここで, 見方を変え, 本調查で収集された全標 本数を対象として T-C 基準值を変化させた時の 高值異常を示すものの割合（スクリーニング率） を試算してみると, $\mathrm{T}-\mathrm{C}$ 基準値 $200 \mathrm{mg} / \mathrm{dl}$ 以上を 高值異常とする場合にはスクリーニング率が男子 で $49.8 \%$, 女子では $50.8 \%$ であり, 以下同様に して基準值 $220 \mathrm{mg} / \mathrm{dl}$ 以上では男子 $28.8 \%$,女 子 $31.1 \%$, 基準值 $230 \mathrm{mg} / \mathrm{dl}$ 以上では男子 20.8 $\%$, 女子 $23.8 \%$, 基準值 $240 \mathrm{mg} / \mathrm{dl}$ 以上では男子 $14.1 \%$, 女子 $17.4 \%$, 基準值 $260 \mathrm{mg} / \mathrm{dl}$ 以上では 男子 $6.3 \%$, 女子 $8.3 \%$ となることが示された。

スクリーニングの効率を少し犠牲にしても, TCの場合には動脈硬化発症の予防効果を高める必 要があるという一次予防の観点に立ち, スクリー ニング率を仮に $20 \%$ となるように設定すると, T $-\mathrm{C}$ 基準值はおよそ $230 \mathrm{mg} / \mathrm{dl}$ 付近と算出される。 ちなみに調査標本から「平均値＋1 SD」を計算す ると, 男子の平均值が $235 \mathrm{mg} / \mathrm{dl}$, 女子では 236 $\mathrm{mg} / \mathrm{dl}$ であり，ほほこの位置に匹敵する。すなわ ち, 当面においては $\mathrm{T}-\mathrm{C}$ の正常上限値を「平均 值 $+2 \mathrm{SD}$ として健診スクリーニングに用いる よりも,「平均値 $+1 \mathrm{SD}$ 值を用いた方が臨床診 断上有意義であり，かつ実用的ではないかと推察 される。勿論, この適切なガイドラインの設定に ついては, 今後, 健診成績の追跡調査を集積した 疫学研究成果を基にして, 各方面から論議されコ ンセンサスを得る必要がある。

地域差に関して,わが国においては通信・運輸・ 文化面ですでに地域レベル差は消失しつつあると する見解が強いが, 本調查 T-C 值においては地域 
的傾向が今なお現存している可能性が示された。 クラスター分析による要因分析の成績からこれを 考察すると, 近年日本人の生活様式が食生活や嗜 好面で欧米化して変貌している状況下に地域と世 代によって多少の差があり，これに連関して T-C レベルが上下しているのではないかと推論され た。橋本ら 9 も, 高齢者における血清脂質濃度の地 域差に関して, 栄養摄取状況, 特に脂肪の摄取量 増加と都市型社会特性が T-Cレベルを上昇させ る主要因子となっている証左を重回帰分析手法を 用いて報告している。さらに，地域差の把握には 栄養調査のみならず，多方面からの分析が必要と なる。本調査で対象とした地域別標本数はわずか 13 地点と少数であるので,さらにデータを追加し て考察すべき余地があると考える。

臨床参考範囲の算出法においては, 現在汎用さ れているいずれの方法を用いても，T-C の算出結 果に大きな違いを認めなかった。これは, 標本に 用いた総合健診受診者データでは異常值の混入が 比較的少ないために分布型の歪みが少ないこと， および予め標本の平均值士 $3 \mathrm{SD}$ を超える極端值 を反復トランケーションして棄却したことの効果 が現れていること等に因るものと考察された。

なお，T-Cについて施設デー夕の互換補正を本 報のように全国的規模で系統的に行った調査・解 析は著者の知る限り本邦で過去に例がなく, 初め ての試みであろうと思われる。今後，本学会の全 国組織を活用して，このようなフィールドにおけ る疫学調查研究が進展し, 国民の健康管理に一層 寄与するデータの集積とその利用が期待される。

\section{結 論}

1) 各施設間の血清総コレステロールの測定値に は，系統的誤差が存在する。

2 ) この施設系統的誤差を是正するために，本調 查ではリファレンス・ラボを設定し, 1989 年 10 月に全国 13 施設で実測された血清総コレ ステロールの健診データを補正一次式により 標準化して, 現在のわが国の值について解析 を行った。

3 ）その結果, 20～69 歳の平均血清総コレステロ ール值は, 男性で 196〜205 mg/dl, 女性では
183〜223 mg/dl が示された。

これらは従来の報告値に比べて高い数値を 示しており，わが国の高脂血症の増加傾向が 現在でも続いている可能性が推測された。

4 ）血清総コレステロールの度数分布型は, 男女 とも正規分布と対数分布型の中間に位置して いた。

基準値算出の方法論についての検討成績で は，確率紙法，パラメトリック法，ノンパラ メトリック法, およびC.R.R.P 法の 4 種の比 較において，それぞれ算出值に大差を認めな かった。

5 ) 血清総コレステロールの総合健診における正 常上限值について，多くの施設で設定してい る『平均値 +2 標準偏差』の值をそのまま適 用することは, 動脈硬化発症のリスクが極め て高いと判断されるので, 検討すべき問題が あるのではないかと推察される。

一次予防を強化する観点からも, 当面, 健 診では『平均值 +1 標準偏差』とする方が適 当ではないかと提案される。この場合，スク リーニング率はおよそ $20 \%$ と試算された。

この適切なガイドラインの設定について は, 今後, 健診成績の追跡調査を集積した疫 学研究を基に, 各方面から論議される必要が ある。

6 ）基準值を一本化すべきかどうかについても検 討課題の一つと考えられる。高齢化社会を迎 えつつある現今，特に加齢による大きな值の 変移を考慮しなければならない場合があると 思われる。

7 ) 全国の血清総コレステロール平均值には地域 差が認められた。クラスター分析により, 地 域（県）間の類似性が示され，ライフスタイ ルや心疾患死亡率とコレステロールレベルと の関係が示唆された。

8 ) 本研究により, 今後, 本学会全国施設をネッ トワークとするフィールド疫学調查の基盤が 築かれ, 予防医学研究を前進させる道筋が示 された。 


\section{謝 辞}

本研究のデー夕集積に当り, 共同研究施設とし て御協力いただいた検査室各位（表 1）に深甚の 謝意を表すとともに，終始御助言を賜わった三井 記念病院副院長 清瀬 闊先生, 並びに牧田総合 病院副院長 笹森典雄先生, 浜松医科大学衛生学 教室 青木伸雄教授に心より感謝申し上げます。 本論文の要旨は日本総合健診医学会第 18 回大会 (1990 年 1 月 26 日, 東京浅草)「指定発言」にて発 表した。

\section{文 献}

1) 日本医師会：昭和 59 年度第 18 回臨床検查精度管理 調查結果報告書, 1984 .

2) Naka, Hajime: An attempt to reduce interlaboratory discrepancies in total cholesterol determination, The 5th International Symposium on Quality
Control-Tokyo proceedings, 337-343, 1983.

3）水野映二, 菅沼源二, 水岡慶二, 新谷和夫, 高原喜八 郎, 清瀬 闊：総合健診医学会施設の 1987 年度生化 学サーベイ報告, 日健診誌，16:291-328，1989.

4）加瀬澤信彦：コレステロールおよびコレステロール エステル比，正常值，141-149，小酒井望・阿部正和 編, 第 3 版, 医学書院, 1983 .

5) 北村元仕, 飯塚悦功：正常值の設定法, 臨床化学, $17: 3-4$ (補冊), 1989.

6） NHK 放送世論調查所：日本人の県民性-NHK 全国 県民意識調査, 集計結果表 $\mathrm{p} 19$, 第 10 問-F, 日本放 送出版協会, 1981 .

7）厚生省公衆衛生局：昭和 55 年循環器疾患基礎調査 報告，財団法人日本心臟財団， 43-57, 1980 .

8）五島雄一郎：高脂血症の治療の最近の考え方, 日本 医事新報 No.3359, 昭和 63 年 9 月 10 日, 1988.

9）橋本修二, 豊嶋英明, 岡本和士, 前田 清, 柳生聖子, 後藤桂葉, 大脇淳子, 加藤孝之：高齢者における血清 脂質濃度の地域差に及ぼす摄取栄養の影響の程度に ついて, 日本公衛誌, $35: 493-500,1988$. 